\title{
An investigation on the Vocational High School Students' Learning Approaches in Terms of Various Variables
}

\author{
Lale Cerrah Ozsevgec ${ }^{1}$, Tugba Kontas Azakli ${ }^{2, *}$ \\ ${ }^{1}$ Faculty of Education, Karadeniz Technical University, Turkey \\ ${ }^{2}$ İkizce Vocational School, Ordu University, Turkey
}

Copyright $\odot 2018$ by authors, all rights reserved. Authors agree that this article remains permanently open access under the terms of the Creative Commons Attribution License 4.0 International License

\begin{abstract}
The purpose of this study is to reveal the relationship among vocational school students' learning attitudes and their socio-demographic features and academic success. Quantitative approach in Relational survey model was used in the study. The sample of the study consists of 82 students who were studying at the Ordu University, during 2015-2016 fall term. The data were collected with learning approach scale. Obtained data indicated that the students mostly prefer deep and strategic learning approaches to surface learning approaches. It was seen that the cumulative grade point average of the participants whose ages older than 20 was higher. There was a significant relationship between the cumulative grade average and deep motivation of the students. Based on the data, it was suggested that awareness of the teachers should be focused on the students' learning approaches.
\end{abstract}

Keywords Learning Approaches, Deep Learning, Surface Learning, Strategic Learning

\section{Introduction}

Since the understanding that learners are not passive listeners who learn what is told, but those who interpret the knowledge within the active learning process, the question "How do individuals learn?" has become the focus point as well as "How are they taught?". The question of how students learn has also revealed the concept of learning approach together. Learning approach concept was first identified by Marton et al. [1]. Learning approach is described as the way of learning that students prefer according to their perception of what is intended to be taught [2]. in literature, students' learning approaches are categorized as deep, surface and strategic. Briefly a deep approach can be described as a way of searching for meaning by converting, surface approach as a way of copying, and strategic approach as a way of organizing. Deep approach to learning is associated with students' intentions to understand and to engage appropriately in meaningful learning, focusing on the main themes and principles and using strategies that are appropriate for creating such meaning [3]. One student may have different approaches in different situations and the way the student perceives the learning environment is influential on his/her learning approach. If the student perceives the learning environment positively, it is indicated that it is a deep approach and if the student perceives it negatively, a superficial approach may be developed. If the student perceives learning environment positively, s/he develops deep approach; if he/she perceives it negatively, surface approach is developed [4].

Today's higher education faces the challenge of not only having to teach students a bulk of domain-specific frameworks and disciplinary insights but also having to foster skills that will enable them to become versatile experts in their own fields and lifelong learners. According to the results of a review study examining how learning approaches change in higher education; do not provide clear empirical evidence for assumption that students develop towards more deep approaches during the higher education [3]. However, changes in approaches to learning over time were related to their self-efficacy beliefs, where students with low levels of self-efficacy decreased in their deep approach and increased their surface approach across time. Students with high levels of self-efficacy demonstrated no such change in approaches to learning [5] in another study, university students from different groups (Low-Middle-High); a small increase in surface approaches was present for the Low group, while the Mid and High groups both presented small increases in deep approaches during the university years. The amount of deep strategies students have when they arrive at a university has long standing implications for the quality of 
their learning across this crucial transition to a university [6].

Knowing learning approaches is regarded as important in terms of students' discovering their ways of receiving information and teachers' identifying and considering students' different approaches in transferring knowledge. So that, it is thought that knowing students' learning approaches is important in terms of the organization of the learning environment and the meaningful learning of the subject [2]. In the studies, it has been determined that the deep learning approach makes a positive contribution to the academic achievement [7-9]. Longitudinal studies are recommended in the literature to examine the relationship between the learning approaches and the success [8].

Exploring the learning approaches of assistant teachers who will take part in the education sector as intermediate staff, is crucial in terms of facilitating both for teachers and the students what they will address in the future. In this direction, the research that will be carried out on learning approaches of university students will enable us both to evaluate the teaching process in the university environment and to deduce about these students' own future teaching environment.

The purpose of this study is to examine the relationship of the vocational high school students' deep and surface learning strategies with socio-demographical features and their academic achievement.

The questions to be answered in this study are as follows: is there a significant relationship between the students' learning approaches; deep approach, surface approach, deep strategy, surface strategy, deep motivation, surface motivation (DA, SA, DS, SS, DM, SM) and their final cumulative grade average (CGPA)? is there a significant relationship between the students' learning strategies (DA, SA, DS, SS, DM, SM) and their socio-demographical situation (age, how many sisters or brothers the student have, parents' educational background, parents' occupations, socio-economic background of the family, situation of the house, what kind of high school they graduate, and the ranking of this choice)?

\section{Materials and Methods}

\subsection{Study Design}

Relational survey method which is one of the quantitative research methods was used in the study. Using this method provided to determine the students' learning approaches and some variables effective on them or not [10].

\subsection{Sample}

The study was carried out with 82 students who were studying at the Department of Child Development, in Fatsa Vocational High School, Ordu University in 2015-2016 fall term.
Table 1. Personal information of the participants

\begin{tabular}{|c|c|c|c|}
\hline & & $\mathrm{n}$ & $\%$ \\
\hline \multirow{2}{*}{ Age } & Younger than 20 years old & 55 & 67.1 \\
\hline & 20 years old or older & 27 & 32.9 \\
\hline Sex & $\begin{array}{l}\text { Male } \\
\text { Female }\end{array}$ & $\begin{array}{c}0 \\
82 \\
\end{array}$ & $\begin{array}{c}0 \\
100 \\
\end{array}$ \\
\hline \multirow{3}{*}{$\begin{array}{c}\text { The number of } \\
\text { the sisters and } \\
\text { brothers }\end{array}$} & One or Two sisters/brothers & 30 & 36.6 \\
\hline & Three sisters/brothers & 29 & 35.4 \\
\hline & Four or more sisters/brothers & 23 & 28.0 \\
\hline \multirow{3}{*}{$\begin{array}{l}\text { Birth order in } \\
\text { the family }\end{array}$} & First & 36 & 43.9 \\
\hline & Second & 33 & 40.2 \\
\hline & Third or fourth child & 13 & 15.9 \\
\hline \multirow{4}{*}{$\begin{array}{l}\text { Educational } \\
\text { background of } \\
\text { mother }\end{array}$} & illiterate & 6 & 7.3 \\
\hline & Primary school graduate & 57 & 69.5 \\
\hline & Secondary school graduate & 9 & 11.0 \\
\hline & $\begin{array}{l}\text { High school or university } \\
\text { graduate }\end{array}$ & 10 & 12.2 \\
\hline \multirow{3}{*}{$\begin{array}{l}\text { Educational } \\
\text { background of } \\
\text { father }\end{array}$} & Primary school graduate & 47 & 57.3 \\
\hline & Secondary school graduate & 16 & 19.5 \\
\hline & $\begin{array}{l}\text { High school or university } \\
\text { graduate }\end{array}$ & 19 & 23.2 \\
\hline \multirow{3}{*}{ Mother age } & Younger than 40 years old & 25 & 30.5 \\
\hline & Between $40-45$ age range & 37 & 45.1 \\
\hline & Over 45 years old & 20 & 24.4 \\
\hline \multirow{4}{*}{ Father age } & Younger than 40 years old & 8 & 9.8 \\
\hline & Between $41-44$ age range & 23 & 28.0 \\
\hline & Between $45-49$ age range & 35 & 42.7 \\
\hline & Over 50 years old & 16 & 19.5 \\
\hline \multirow{2}{*}{$\begin{array}{l}\text { Mother } \\
\text { occupation }\end{array}$} & Housewife & 71 & 86.6 \\
\hline & Working & 11 & 13.4 \\
\hline \multirow{3}{*}{$\begin{array}{c}\text { Father } \\
\text { occupation }\end{array}$} & Self-employed/Tradesman & 28 & 34.1 \\
\hline & Labourer /Officer & 38 & 46.3 \\
\hline & Retired/Farmer & 16 & 19.5 \\
\hline \multirow{3}{*}{$\begin{array}{l}\text { Family Socio- } \\
\text { eco. situation }\end{array}$} & Between 0-1000 tl & 49 & 59.8 \\
\hline & Between 1000-2000 tl & 21 & 25.6 \\
\hline & Over $2000 \mathrm{tl}$ & 12 & 14.6 \\
\hline \multirow{2}{*}{$\begin{array}{l}\text { Situation of } \\
\text { house }\end{array}$} & Their own & 55 & 67.1 \\
\hline & Rent & 27 & 32.9 \\
\hline \multirow{5}{*}{$\begin{array}{c}\text { Ranking of } \\
\text { school choice }\end{array}$} & $1^{\text {st }}$ choice & 27 & 32.9 \\
\hline & $2^{\text {nd }}$ choice & 14 & 17.1 \\
\hline & $3^{\text {rd }}$ or $4^{\text {th }}$ choice & 12 & 14.6 \\
\hline & Between $5^{\text {th }}$ and $10^{\text {th }}$ choice & 14 & 17.1 \\
\hline & $11^{\text {th }}$ or next choice & 15 & 18.3 \\
\hline \multirow{2}{*}{$\begin{array}{l}\text { Graduated } \\
\text { school }\end{array}$} & Vocational school for girls & 67 & 81.7 \\
\hline & Others & 15 & 18.3 \\
\hline
\end{tabular}

\subsection{Data Collection Tool}

Personal information Form which was developed by the 
researches in order to determine the socio-demographical features of the participants was used in the study. Students' learning approaches were determined using with Learning Approaches Scale which was developed by Bigs [11]. Bati et al. [12] adapted the scale into Turkish and its validity and reliability were ensured by them. The scale consists of 20 items. There are two subscales, each of which consists of five items and are two determinants. These are Deep Approach (DA) and Superficial Approach (SA). All materials are made up of simple and understandable expressions that target the easy use of the trainers. Scale is questioning the attitudes of learners towards learning and ways of learning. Deep approach level of a student can be calculated by summing the points of $1,2,5,6,9,10,13,14$, 17 and 18 questions; 1, 5, 9,13 and 17 deep motivation; 2 , $6,10,14$ and 18 materials are the decisive factors for the deep strategy. The superficial approach can be calculated by summing the scores of $3,4,7,8,11,12,15,16,19$ and 20 questions. $3,7,11,15$ and 19 are superficial motivations, $4,8,12,16$ and 20 are the decisive factors for the superficial strategy. The total scale score for each approach ranges from 10 to 50 . There are items like "i think you give me a deep pleasure to work" on the scale.

In all subdimensions, the Comparative Fit index (CFi) was $>0.9$, the Standardized Root-Mean-Square Residual (SRMR) and the Root Mean Square Error of Approximation (RMSEA) were $<0.08$. Cronbach Alpha value was calculated as 0.772 and 0.80 , for Deep and Surface Learning Approaches, respectively. Both values were in the acceptable range. Results of the test-retest analyses revealed correlation coefficients of 0.68 and 0.60 $(p<0.01)$, for Deep and Surface Learning Approaches, respectively. In this study, Cronbach's alpha number of the Learning Approach Scale was found to be ".70".

Students' end-of-term grades were obtained via using the university grading system with approval from the students.

\subsection{Data Analysis}

The data were analyzed with SPSS 23 and it was studied with 95\% reliability level. Spearman Correlation, Mann Whitney, Kruskal Wallis which are among the non-parametric test techniques and $\mathrm{t}$ tests which are parametric test techniques were used in the study. Spearman Correlation test was used to determine the direction and strength of the linear relationship between the points obtained from the scale. Mann Whitney was to compare two independent groups in terms of a quantitative variable, and Kruskal Wallis was also used to compare independent $\mathrm{k}$ group $(\mathrm{k}>2)$ in terms of a quantitative variable.

The scores of Surface Motivation, Surface Strategy and Surface Approach, and the situation of showing difference of Grade Point Averages according to the demographical variables were analyzed with t-test, and Deep Motivation, Deep Strategy and Deep Approach scores according to demographic variables were analyzed by Mann Whitney and Kruskal Wallis tests.

Table 2. Descriptive analysis of scale points

\begin{tabular}{|c|c|c|c|c|c|}
\hline & $\mathrm{n}$ & Minimum & Maximum & Average & Std. Deviation \\
\hline Deep Approach & 82 & 24.00 & 50.00 & 33.75 & 5.68 \\
\hline Surface Approach & 82 & 16.00 & 43.00 & 28.26 & 5.07 \\
\hline Deep Motivation & 82 & 11.00 & 25.00 & 16.28 & 3.11 \\
\hline Deep Strategy & 82 & 12.00 & 25.00 & 17.43 & 3.08 \\
\hline Surface Motivation & 82 & 6.00 & 20.00 & 12.45 & 2.97 \\
\hline Surface Strategy & 82 & 9.00 & 23.00 & 15.82 & 3.11 \\
\hline Cumulative Grade Point Average & 82 & 48.50 & 93.50 & 70.57 & 11.47 \\
\hline
\end{tabular}

As seen in the Table 2, the point average of Deep Approach is $33.75 \pm 5.68$; point average of Surface Approach is 28.26 \pm 5.07 ; point Average of Deep Motivation is 16.28 \pm 3.11 ; point average of Deep Strategy is 17.43; 3.08; point average of Surface Motivation is $12.45 \pm 2.97$; point average of Surface Strategy is $15.82 \pm 3.11$ and Cumulative Grade Point Average is $70.57 \pm 11.47$.

Table 3. Normality test findings of scale points

\begin{tabular}{|c|c|c|c|}
\hline & \multicolumn{3}{|c|}{ Shapiro-Wilk } \\
\hline & Statistics & s. d. & p \\
\hline Deep Approach & .96 & 82 & .01 \\
\hline Surface Approach & .97 & 82 & .00 \\
\hline Deep Motivation & .94 & 82 & .03 \\
\hline Deep Strategy & .96 & 82 & $.09^{*}$ \\
\hline Surface Motivation & .97 & 82 & $.14^{*}$ \\
\hline Surface Strategy & .97 & 82 & $.17^{*}$ \\
\hline
\end{tabular}


The Table 3 shows that there is not a normal distribution in the comparative analysis of Deep Approach, Deep Motivation and Deep Strategy $(\mathrm{p}<0.05)$. Because of it non-parametric statistical methods were used. On the other hand, there is normal distribution in the comparative analysis of Surface Approach, Surface Motivation, Surface Strategy and Grade Point Average. So that parametric statistical methods were used for their analysis.

Table 4. Relationship analysis of scale points

\begin{tabular}{|c|c|c|c|c|c|c|c|c|}
\hline & & $\begin{array}{c}\text { Cumulative } \\
\text { Grade } \\
\text { Point } \\
\text { Average }\end{array}$ & $\begin{array}{c}\text { Deep } \\
\text { Approach }\end{array}$ & $\begin{array}{c}\text { Surface } \\
\text { Approach }\end{array}$ & $\begin{array}{c}\text { Deep } \\
\text { Motivation }\end{array}$ & $\begin{array}{c}\text { Deep } \\
\text { Strategy }\end{array}$ & $\begin{array}{c}\text { Surface } \\
\text { Motivation }\end{array}$ & $\begin{array}{l}\text { Surface } \\
\text { Strategy }\end{array}$ \\
\hline \multirow{3}{*}{$\begin{array}{c}\text { Cumulative } \\
\text { Grade Point } \\
\text { Average }\end{array}$} & $r$ & 1 & .17 & -.14 & $.23^{*}$ & .10 & -.16 & -.02 \\
\hline & $p$ & & .11 & .19 & .03 & .34 & .14 & .84 \\
\hline & $n$ & & 82 & 82 & 82 & 82 & 82 & 82 \\
\hline \multirow{3}{*}{ Deep Approach } & $r$ & & 1 & $-.32^{* *}$ & $.89^{* *}$ & $.90^{* *}$ & $-.29^{* *}$ & $-.26^{*}$ \\
\hline & $p$ & & & .00 & .00 & .00 & .00 & .01 \\
\hline & $n$ & & & 82 & 82 & 82 & 82 & 82 \\
\hline \multirow{3}{*}{$\begin{array}{c}\text { Surface } \\
\text { Approach }\end{array}$} & $r$ & & & 1 & $-.30^{* *}$ & $-.29^{* *}$ & $.78^{* *}$ & $.77^{* *}$ \\
\hline & $p$ & & & & .00 & .00 & .00 & .00 \\
\hline & $n$ & & & & 82 & 82 & 82 & 82 \\
\hline \multirow{3}{*}{ Deep Motivation } & $r$ & & & & 1 & $.64^{* *}$ & -.21 & $-.25^{*}$ \\
\hline & $p$ & & & & & .00 & .05 & .02 \\
\hline & $n$ & & & & & 82 & 82 & 82 \\
\hline \multirow{3}{*}{ Deep Strategy } & $r$ & & & & & 1 & $-.30^{* *}$ & $-.24^{*}$ \\
\hline & $p$ & & & & & & .00 & .02 \\
\hline & $n$ & & & & & & 82 & 82 \\
\hline \multirow{3}{*}{$\begin{array}{c}\text { Surface } \\
\text { Motivation }\end{array}$} & $r$ & & & & & & 1 & $.31^{* *}$ \\
\hline & $p$ & & & & & & & .00 \\
\hline & $n$ & & & & & & & 82 \\
\hline
\end{tabular}

$* * \mathrm{p}<0.01, * \mathrm{p}<0.05$

The findings of correlation analysis, there is a positive but weak relationship between the Grade Point Average and Deep Motivation points $(r=.23 ; \mathrm{p}<0.05)$. There is a negative but weak relationship between Deep Approach points and Surface Approach, Surface Motivation and Surface strategy points $(r=-.32 ; r=-.29 ; \mathrm{r}=-.26 ; \mathrm{p}<0.05)$. But there is a positive and strong relationship with the points of Deep Motivation and Deep Strategy $(r=.89 ; \mathrm{r}=.90 ; \mathrm{p}<0.05)$.

As it seen in the table there is a negative and weak relationship between the points of Surface Approach and the points of Deep Motivation and Deep Strategy $(\mathrm{r}=-.30 ; \mathrm{r}=-.29 ; \mathrm{p}<0.05)$; but it has a positive and strong relationship with the Surface Motivation and Surface Strategy points $(\mathrm{r}=.78 ; \mathrm{r}=.77 ; \mathrm{p}<0.05)$.

Table 4 shows that there is a positive and moderate relationship between Deep Motivation and Deep Strategy points $(\mathrm{r}=.64 ; \mathrm{p}<0.05)$; but negative and weak relationship with Surface Strategy points $(\mathrm{r}=-.25 ; \mathrm{p}<0.05)$. There is a negative and weak relationship between the points of Deep Strategy and the points of Surface Motivation and Surface Strategy ( $\mathrm{r}=-.30$; $\mathrm{r}=-.24 ; \mathrm{p}<0.05)$. At Last there is a positive and weak relationship between Surface Motivation and Surface Strategy ( $\mathrm{r}=.31$; $\mathrm{p}<0.05)$.

Table 5. A comparison of age groups with regards to scale scores

\begin{tabular}{|c|c|c|c|c|c|c|}
\hline & Age & $\mathrm{N}$ & Average & Std. Sapma & $\mathrm{t}$ & $\mathrm{P}$ \\
\hline \multirow{2}{*}{ Surface Approach } & Younger than 20 years old & 55 & 28,527 & 5,301 & \multirow{2}{*}{.65} & \multirow{2}{*}{.51} \\
\hline & 20 years old and over & 27 & 27,740 & 4,637 & & \\
\hline \multirow{2}{*}{ Surface Motivation } & Younger than 20 years old & 55 & 12,509 & 3,084 & \multirow{2}{*}{.25} & \multirow{2}{*}{.80} \\
\hline & 20 years old and over & 27 & 12,333 & 2,801 & & \\
\hline \multirow{2}{*}{ Surface Strategy } & Younger than 20 years old 20 & 55 & 15,981 & 3,308 & \multirow{2}{*}{.63} & \multirow{2}{*}{.53} \\
\hline & 20 years old and over & 27 & 15,518 & 2,708 & & \\
\hline \multirow{2}{*}{$\begin{array}{l}\text { Grade Point } \\
\text { Average }\end{array}$} & Younger than 20 years old & 55 & 72,490 & 11,168 & \multirow{2}{*}{2.21} & \multirow{2}{*}{$.03^{*}$} \\
\hline & 20 years old and over & 27 & 66,666 & 11,297 & & \\
\hline
\end{tabular}


According to the findings of t-Test, there is a statistically significant difference between age groups with regard to Grade Point Average. Grade point averages of those who are younger than 20 years is 72,490 ; those 20 and over is 66,666 . Table 5 also shows that, there is not any statistically significant difference between the age groups in terms of the points of Surface Approach, Surface Motivation and Surface Strategy $(\mathrm{p}>0,05)$.

\section{Conclusions and Discussion}

As a result of the analyses, it was determined that the students mostly preferred deep and strategic learning approaches at a more significant level to surface approach. There are similar results in studies conducted with teacher candidates in the literature [13, 14].

Based on the findings it was concluded that there is a significant relation between the Cumulative Grade Point Average and Deep Motivation points of the students. More over the cumulative grade point average of the participants who are older than 20 years is higher. Some of the studies in literature also revealed that there is a significant relationship between the students' academic success and their deep and strategic learning $[7,9,15]$. According to Selcuk et al. [14] working with teacher candidates; as the class level gets higher, students' approaches to deep learning are increasing. in this study, as the age of the students increases, the academic achievement increases and as the academic achievement increases, deep learning approaches increase. This may be due to an increase in the depth of learning with age.

There is statistically significant difference between the situation of house groups with regard to the scores of Surface Approach and Surface Motivation. According to this finding, it was concluded that those who own their houses have higher scores of Surface Approach and Surface Motivation. From this aspect, the findings of this study are consistent with literature. In the literature some of the researches point out a significant relationship between the deep learning approach and gender in favour of females and a significant relationship between the surface learning and gender in favour of males $[13,16]$. However, there is also finding shows no significant relationship between the gender and learning approaches [17]. Because of the department all participants of this study were female and according to the findings of the study most of them preferred deep learning approach as it noted in the literature. Other result of the study is absence of relationship between the learning approaches and demographical features Besoluk et al. [13] also stated same result.

Lastly, it was found that there isn't a significant relationship between the students' learning strategies (DA, SA, DS, SS, DM, SM) and their socio-demographical features (age, the number of the sisters and brothers, their birth order in the family, educational background of the parents, parents' occupations, socio-economic background of the family, the type of the high school they graduate, and the ranking of this choice).

\section{Suggestions}

This study was carried out with female students of a vocational higher school in Turkey. For the future studies it is suggested to be carried out same researches with different age and gender groups. As a follow up study, qualitative studies can be carried out in order to determine the factors that affect the learning approaches of the students who have over achievement.

Longitudinal studies can be conducted with the students in order to examine the role of learning approaches on the academic success and students' development and preferences may be followed in this process. Lecturers to present information to vocational high school students in more practical ways can have a positive effect on the learning of students with a deep learning approach. For students with a strategic learning approach, a non-graded approach to education may enhance the in-depth learning of these students. The inclusion of students in meaningful and critical learning activities in higher education and the enhancement of these activities are necessary.

\section{Acknowledgements}

We are very grateful to experts for their appropriate and constructive suggestions to improve this template.

\section{REFERENCES}

[1] Ference, M. \& Säljo, R. On qualitative differences in learning: i-Outcome and process. British journal of educational psychology 46.1 (1976): 4-11.

[2] Ilkorucu-Gocmencelebi, S. "Derin-Yuzeysel ve Staratejik (Basari) Ogrenme Ogretme Yaklasimlari’. In: Ekici, G, editor. "Etkinlik Ornekleriyle Guncel Ogrenme Ogretme Yaklasimlari” Ankara: Pegem Akademi, 2014; p.148-186

[3] Asikainen, H., \& Gijbels, D. Do students develop towards more deep approaches to learning during studies? A systematic review on the development of students' deep and surface approaches to learning in higher education. Educational Psychology Review. 2017 [Cited 2017 Nov 10] $1-30$.

[4] Entwistle, N. J. \& Peterson E.R. Conceptions of learning and knowledge in higher education: Relationships with study behavior and influences of learning environments. International journal of educational research. 2004 [Cited 2014 May 20] 41.6: 407-428.

[5] Prat - Sala, M., \& Redford, P. The interplay between 
motivation, self - efficacy, and approaches to studying. British Journal of Educational Psychology. 2010, 80(2), 283-305.

[6] Fryer, L. K. (Latent) transitions to learning at university: A latent profile transition analysis of first-year Japanese students. Higher Education. 2017, 73(3), 519-537.

[7] McManus, i. C., Richards, P., \& Winder, B. C. intercalated degrees, learning styles, and career preferences: prospective longitudinal study of UK medical students. 1999, Bmj, 319(7209), 542-546.

[8] Burton, L. J., \& Nelson, L. The relationships between personality, approaches to learning, and academic success in first-year psychology distance education students. in Proceedings of the 29th HERDSA Annual Conference: Critical Visions: Thinking, Learning and Researching in Higher Education. HERDSA 2006, Vol. 29, pp. 64-72. Higher Education Research and Development Society of Australasia (HERDSA).

[9] Chamorro-Premuzic, T., \& Furnham, A. Personality, intelligence and approaches to learning as predictors of academic performance. Personality and individual differences. 2008, 44(7), 1596-1603.

[10] Karasar, N. (1995). Scientific Research Methodology. Ankara: 3A Research Education Consultancy

[11] Biggs, J. B. Student Approaches to Learning and Studying.
Research Monograph. Australian Council for Educational Research Ltd., Radford House, Frederick St., Hawthorn 3122, Australia., 1987.

[12] Bati, A.H., Tetik, C. \& Gurpinar, E. Assessment of the Validity and Reliability of the Turkish Adaptation of the Study Process Questionnaire (R-SPQ-2F). Turkiye Klinikleri J Med Sci, 2009 .30(5):1639-46

[13] Besoluk, S., \& Onder, i. investigation of teacher candidates' learning approaches, learning styles and critical thinking dispositions. Elementary Education Online. 2010, 9(2), 679-693.

[14] Selcuk, G. S., Caliskan, S., \& Erol, M. Evaluation of Learning Approaches for Prospective Physics Teachers'. Gazi University Journal of Gazi Educational Faculty (GUJGEF), 2007, (2).

[15] Ekinci, N. Learning approaches of university students. Education and Science, 2009, 34(151), 74

[16] Ozan, C., Kose, E. \& Gundogdu, K. Analysis of approaches to learning of students in preschool and primary school teaching departments]. Journal of Educational Sciences Research. 2012, 2 (2), 75-92.

[17] Ozan, C., \& Ciftci, M. Analysis of Approaches to Learning Preferences and Perceptions of Learning of Students in Faculty of Education. Pegem Journal of Education and Instruction. 2013, 3(1), 55-66. 